\title{
Vaccination of Shrimp (Litopenaeus vannamei) against White Spot Syndrome Virus (WSSV) by Oral Vaccination of Recombinant Fusion Protein, rVP19+28
}

\author{
Thi-Hoai Nguyen, Yeong Jin Kim, Mi Ran Choi and Sung-Koo Kim* \\ Department of Biotechnology, Pukyong National University, Busan 608-737, Korea
}

Received June 14, 2010 /Accepted July 26, 2010

\begin{abstract}
This study was carried out to evaluate the vaccination effects of recombinant fusion protein rVP19+28 against WSSV in shrimp, Litopenaeus vannamei. The VP19+28 gene fused with VP19 and VP28 genes was inserted into pET-28a $(+)$ expression vector and cloned in E. coli BL21 (DE3) to produce fused gene product recombinant VP19+VP28 as a single protein. For the vaccination, the shrimps were fed with pellets coated with purified recombinant protein, rVP19+28, for 2 weeks. Then, constant amounts of WSSV at $1 \times 10^{2}$ diluted stocks were injected to the muscle of the shrimp for the in vivo challenge tests. Non-vaccinated shrimps showed a cumulative mortality of $100 \%$ at 11 days post-challenge. The shrimps vaccinated with the inactivated $E$. coli BL21 as a host cell control showed cumulative mortality of $100 \%$ at 17 days post-challenge. The shrimps vaccinated with rVP19, rVP28 and rVP19+28 showed mortalities of $66.7 \%, 41.7 \%$ and $41.7 \%$ at 21 days post-challenge, respectively. These results indicated that the rVP28 and rVP19+28 had relatively high vaccination effects against WSSV infection. However, this study suggests that the fusion protein rVP19+28 was more effective for the protection of shrimp against WSSV than rVP28, even though the cumulative mortalities were the same 21 days post-challenge.
\end{abstract}

Key words: WSSV, VP19, VP28, fusion protein, Litopenaeus vannamei

\section{Introduction}

White spot syndrome virus, WSSV is $305 \mathrm{~kb}$ doublestranded DNA virus belongs to monotypic family Nimaviridae, genus Whispovirus with a wide host range among crustaceans [8]. WSSV infection causes 100\% mortality within 7 to 10 days in commercial shrimp culture pond, resulting in large economical losses to the shrimp culture industry [10].

The virus particle of WSSV consists of 6 major proteins such as VP15, VP19, VP24, VP26, VP28 and VP664. In addition to major proteins, 40 WSSV proteins have been characterized [1]. VP19 and VP28 were identified as envelop proteins. VP2 8 has been demonstrated as an important viral protein for initial stages of WSSV infection [6].

The envelop proteins of virus usually play important roles in virus infection and assembly [3]. Therefore, envelop proteins can be useful tools to produce antibody and vaccine. It has been regarded that a true adaptive immune response system is lacked in invertebrates except innate immune responses as a cellular immunity. However, the recent reports

*Corresponding author

Tel : +82-51-629-5868, Fax : +82-51-629-5868;

E-mail : skkim@pknu.ac.kr suggested that an adaptive immune response with shortterm memory exists in shrimp as a defense system for the infection [2]. Studies on the shrimp immune response to viral infections are still limited, although the presences of viral gene expression inhibiting proteins and specific up-regulation of genes upon viral infection have been demonstrated [4,5]. In vivo experiments with Penaeus japonicus demonstrated the presence of a quasi-immune response when WSSV survivors of both natural and experimental infections were re-challenged with WSSV [7]. Plasma of the surviving infected shrimps could neutralize WSSV from 20 days up to 2 months after the infection [10]. These results suggest that adaptive immune responses could exist in shrimp and the vaccination of shrimp against WSSV might be possible. The major route of WSSV infection is the vertical transmission by WSSV infected broodstock. However, the horizontal transmission of WSSV, both by cannibalism and water-borne exposure, is also an important infection route in shrimp. Because the injection vaccination is not practically suitable in shrimp culture, an oral vaccination on the basis of cannibalism was adopted as an effective vaccination method.

This study was carried out to evaluate the recombinant fusion protein rVP19+28 including both VP19 and VP28 as 
quasi-vaccines for the oral administration.

\section{Materials and Methods}

\section{Shrimp culture}

Healthy shrimps (Litopenaeus vannamei) were purchased from a shrimp farm located Muan, Jeonnam, Korea. Shrimps of 6 to $8 \mathrm{~g}$ were used in experiments. Shrimps were kept in tanks at $26^{\circ} \mathrm{C}$ and each shrimp was placed in individual plastic cages to prevent cannibalism [9]. PCR detection was carried out with WSSV specific primers to ensure previous WSSV exposure before experimental infection.

\section{WSSV stock and virus titration}

WSSV infected shrimps were homogenized in 10-fold volumes of phosphate buffered saline (PBS) at $4^{\circ} \mathrm{C}$ and centrifuged at $12,000 \times g$ for $10 \mathrm{~min}$ at $4^{\circ} \mathrm{C}$. The supernatant was filtered through a $0.45 \mu \mathrm{m}$ filter and used as the virus stock for challenge test. The virus stock was serially diluted from $1 \times 10^{1}$ to $1 \times 10^{5}$ times in PBS and titrated in vivo as described in Table 1. Ten $\mu \mathrm{l}$ of different virus dilutions were injected in the second abdominal segment of the shrimp using a 30-gauge needle. For each group, fifteen shrimps were used in the challenge test. Mortality was recorded daily and dead shrimps were tested for the presence of WSSV by PCR. The time-mortality relationship was used to determine an optimal pressure for the challenge test.

\section{Construction of recombinant plasmid pET-VP19+28}

WSSV genomic DNAs were extracted from the WSSV stock using Genomic DNA Extraction Kit (Bioneer, Daejeon, Korea). The DNA fragment encoding the entire VP19 and VP28 ORF was amplified from genomic WSSV DNA by PCR using VP19 primers sets (F: 5'-CGGAATTCATGGCCAC CACGAC-3', R: 5'-GGGATCCCTGCCTCCTCT TG-3') and VP28 primer sets (F: 5'-CGGGATCCATGGATCTTTCTTTCAC-3', R: 5'-A CGCGTCGACCTCGGTCTCAGTG-3'). PCR was performed under following conditions: $95^{\circ} \mathrm{C}$ for $5 \mathrm{~min}, 30$ cycles

Table 1. Experimental design for in vivo titration by injection

\begin{tabular}{clc}
\hline Group & Injection $(50 \mu \mathrm{l} /$ shrimp $)$ & No. of shrimp \\
\hline Negative control & $50 \mu$ l of $1 \times$ PBS & 20 \\
1 & $10^{1}$ of WSSV dilution & 20 \\
2 & $10^{2}$ of WSSV dilution & 20 \\
3 & $10^{3}$ of WSSV dilution & 20 \\
4 & $10^{4}$ of WSSV dilution & 20 \\
5 & $10^{5}$ of WSSV dilution & 20 \\
\hline
\end{tabular}

at $95^{\circ} \mathrm{C}$ for $30 \mathrm{sec}, 55^{\circ} \mathrm{C}$ for $30 \mathrm{sec}$ and $72^{\circ} \mathrm{C}$ for $30 \mathrm{sec}$, followed by an extension period at $72^{\circ} \mathrm{C}$ for $5 \mathrm{~min}$. The amplified VP19 of 365 bp and VP28 of 614 bp DNA fragments were cut by same restriction enzyme Bam $\mathrm{HI}$ and then ligated by $\mathrm{T} 4$ ligase at $16^{\circ} \mathrm{C}$ for $10 \mathrm{hr}$. The VP19+28 gene was inserted into pET-28a $(+)$ expression vector (Novagen, Darmstadt, Germany). The presence of the insert in the plasmid was confirmed by colony PCR and digestion with Eco RI and Sal I.

The recombinant plasmids were sequenced at Macrogen. Ltd. (Seoul, Korea). The comparison of nucleotide sequence of VP19+28 gene was performed with BLAST (NCBI, USA). The resulting recombinant plasmid was named pET-VP19+28.

Expression and purification of recombinant fusion protein rVP19+28

The recombinant plasmid, pET-VP19+28, was cloned into E. coli BL21 and the protein was expressed by the addition of $0.4 \mathrm{mM}$ IPTG for $2 \mathrm{hr}$ at $37^{\circ} \mathrm{C}$. Cells were disrupted by the sonication with $8 \mathrm{M}$ urea, and then centrifuged at $12,000 \times g$ for $20 \mathrm{~min}$ at $4^{\circ} \mathrm{C}$. Dialysis of the supernatant was carried out using the membrane with molecular cut off of 12,000-14,000 (Spectrum Laboratories, Inc., Houston, USA) in TE buffer to remove the urea.

His-tagged rVP19+28 was purified using a Ni-Sepharose high performance resin open column (GE Healthcare Bio-science, Uppsala, Sweden). The supernatants were passed through a $0.45 \mu \mathrm{m}$ syringe filter before purification. After the equilibrium of sample with binding buffer $(20 \mathrm{mM}$ Tris- $\mathrm{Cl}, 0.5 \mathrm{M} \mathrm{NaCl}, \mathrm{pH} 8.0$ ), the column was washed with binding buffer and then eluted with elution buffer $(20 \mathrm{mM}$ Tris, $0.5 \mathrm{M} \mathrm{NaCl}, 500 \mathrm{mM}$ Imidazole, $\mathrm{pH} 8.0$ ). The purified protein was further concentrated by Amicon Ultra $30 \mathrm{~K}$ (Millipore, Bedford, USA). The molecular weight of purified rVP19+28 was determined by SDS-PAGE $(12 \%$ acrylamide gel), and the concentration of protein was determined by the Bradford assay (Bio-Rad, Hercules, USA).

\section{Preparation of feed pellets for vaccination}

Commercial pellets weighing approximately 10 grams were mixed with $5 \mathrm{ml}$ PBS containing $1 \mathrm{mg}$ of purified rVP19, rVP28 and rVP19+28 protein, respectively. E. coli BL21 and PBS were used for the host cell and negative control. The recombinant proteins were subsequently mixed with the feed pellets and incubated on ice to allow absorption of the suspension with FCA (Freund's Complete 
Table 2. Contents of experimental groups used in the challenge tests for vaccination

\begin{tabular}{clc}
\hline Experimental group & Contents for vaccination & No. of shrimp \\
\hline Negative control & Commercial feed & $15 \times 3$ \\
Positive control & Commercial feed & $15 \times 3$ \\
E. coli BL21 & E. coli + feed + FCA & $15 \times 3$ \\
rVP19 & E. coli + rVP19 + feed + FCA & $15 \times 3$ \\
rVP28 & E. coli + rVP28 + feed + FCA & $15 \times 3$ \\
rVP19+28 & E. coli + rVP19+28 + feed + FCA & $15 \times 3$ \\
\hline
\end{tabular}

Adjuvant; Sigma, St. Louis, USA) to prevent dispersion of the recombinant protein suspension in the water.

\section{Oral vaccination and in vivo challenge tests}

The healthy shrimps without the virus were divided into six groups as described in Table 2 for the challenge tests. Four groups were vaccinated by feeding the pellets coated with $E$. coli host, rVP19, rVP28 and rVP19+28 for 14 days as indicated in Table 2. After the vaccination, $10 \mu$ of WSSV stocks $\left(1 \times 10^{2}\right)$ were intramuscularly injected into shrimps. After the injection, the shrimp mortality was monitored daily. The experiments were conducted in triplicate.

\section{Results}

\section{Preparation of recombinant fusion protein VP19+28}

The production of $\mathrm{rVP} 19+28$ was carried out from the cloned E.coli. After the cloning, digestions of pET-VP19+28 were carried out with EcoR I and Sal I and the restriction map was prepared as shown in Fig. 1. The band of VP19+28 gene was observed at the position of $979 \mathrm{bp}$ indicating correct construction of pET-VP19+28. The protein was expressed at $37^{\circ} \mathrm{C}$ for $2 \mathrm{hr}$ of induction with $0.4 \mathrm{mM}$ IPTG
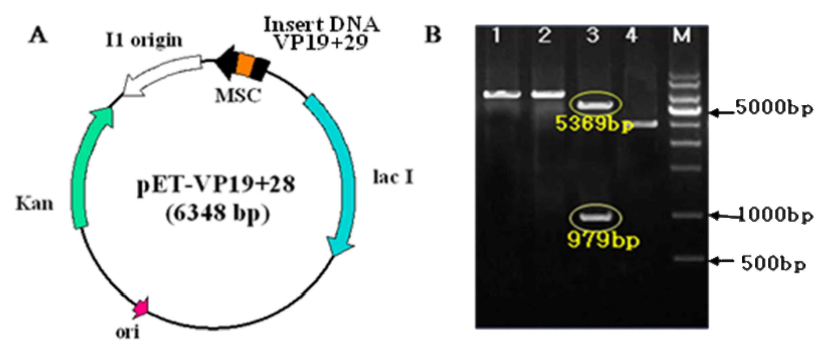

Fig. 1. Recombinant plasmid pET-VP19+28 and restriction patterns. (A) pET-VP19+28 with the size of $6348 \mathrm{bp},(B)$ restriction patterns using $E c d R$ I and Sal I. lane 1, one cut fragment with $E c d R$ I; lane 2, one cut fragment with Sal I; lane 3, two cut fragments with EcoR I and Sal I; lane 4, uncut recombinant plasmid pET-VP19+28; M, 1 $\mathrm{kb}$ DNA ladder marker. as an optimal expression condition. After the expression, the purification of $\mathrm{rVP} 19+28$ was carried out with Ni-Sepharose and Amicon Ultra membrane. The purified protein was confirmed by SDS-PAGE (12\% acrylamide gel) as shown in Fig. 2A. The band was observed at the expected position of 45 $\mathrm{kDa}$ corresponding to rVP19+28. In the western blot analysis, the rVP28 antiserum showed a clear reaction with $\mathrm{rVP19}+28$ with correct molecular weight of $44 \mathrm{kDa}$ as shown in Fig. 2B.

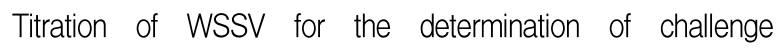

Titration of WSSV for the determination of challenge pressure

For the determination of dilution ratio resulting $100 \%$ mortality of shrimp in desired period of experiments, in vivo virus titration was performed. As shown in Fig. 3, the results of in vivo titration showed $50-100 \%$ mortalities in all tested groups at 14 days of post challenge. Administration of virus dilutions of $1 \times 10^{1}$ and $1 \times 10^{2}$ resulted in $100 \%$ mortality in less than 9 days of post challenge. However, the dilutions of $1 \times 10^{3}, 1 \times 10^{4}$ and $1 \times 10^{5}$ resulted in final mortalities of $95 \%$, $65 \%$ and $40 \%$ at 14 days of post challenge. Therefore, the virus dilution of $1 \times 10^{2}$ was chosen as the optimal pressure
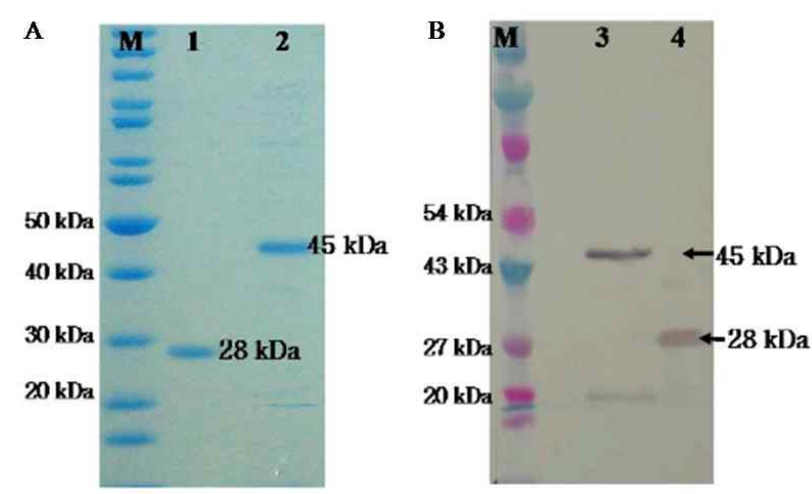

Fig. 2. Identification of expressed recombinant protein rVP28 and rVP19+28. (A) SDS-PAGE. M, ProSieve-Color protein ladder marker; lane 1, rVP28; lane 2, rVP19+28, (B) western blot analysis. $\mathrm{M}$, Protein molecular weight standard marker; lane 3, rVP19+28; lane 4, rVP28. 


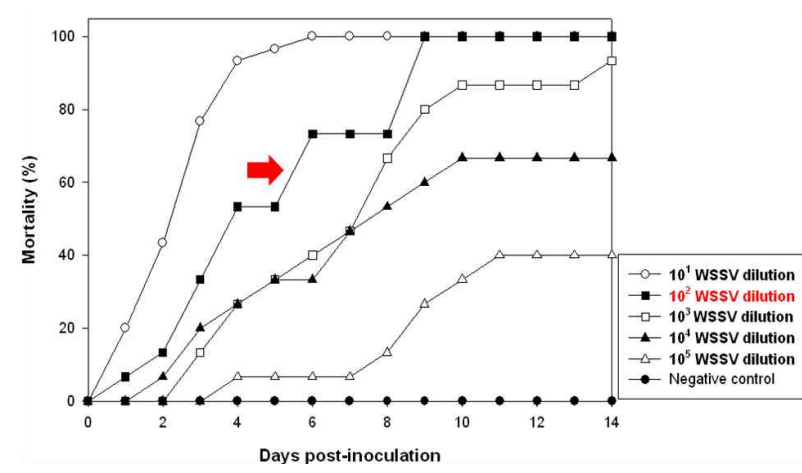

Fig. 3. WSSV titration for the determination of optimal challenge pressure. Ten $\mu \mathrm{l}$ of $1 \times 10^{1}, 1 \times 10^{2}, 1 \times 10^{3}, 1 \times 10^{4}$ and $1 \times 10^{5}$ diluted WSSV stock were injected intramuscularly to $L$. vannamei.

for the challenge tests.

\section{Efficacy of oral vaccination against WSSV}

After the vaccination and challenge tests, the time-mortality relationship was obtained and shown in Fig. 4. All shrimps in negative control survived, whereas the shrimps in the positive control showed cumulative mortality of $100 \%$ at 11 days of post challenge. The shrimps vaccinated with the inactivated E. coli BL21 as a host cell control showed cumulative mortality of $100 \%$ at 17 days of post challenge. The shrimps vaccinated with rVP19, rVP28 and rVP19+28 showed $66.7 \%, 41.7 \%$ and $41.7 \%$ of mortalities at 21 days of post challenge, respectively. These results indicated that the rVP28 and rVP19+28 had the relative high vaccination effects against WSSV infection.
Fig. 4. Cumulative mortalities of $L$ vannamei challenged with WSSV by injection after the oral vaccination. Each point represented the average of triplicate tests. The compositions and treatments for six experimental groups were described in Table 2 .

\section{Discussion}

The vaccination of shrimp against viral pathogens is uncertain due to the lack a known adaptive immune response in shrimp. However, recent reports suggested that the presence of such a response in crustaceans [7]. The possibility of vaccination as an intervention strategy for viral disease in shrimp has been evaluated.

The major route of WSSV infection is the horizontal transmission by cannibalism and water-borne exposure as well as the vertical transmission by WSSV infected broodstock. Cannibalism was recognized one of the most important modes of WSSV transmission because shrimp mortality decreased when cannibalism was prevented in the infection experiment [10]. Therefore, oral vaccination on the basis of cannibalism was more suitable than injection vaccination for the protection from WSSV infection in shrimp farms.

Because VP19 and VP28 are exposed proteins abundantly present on the WSSV envelop and thus likely to be the first molecular to contact with host cells [6]. Fusion protein is easier to manipulate than two separate proteins with respect to cloning, expression, purification and antibody production. Hence, the fusion protein of VP19 and VP28 was regarded as an effective vaccine for the protection of shrimp against WSSV.

In this study, the vaccinated shrimps by oral feeding showed low cumulative mortalities compared to control groups. The rVP28 and rVP19+28 had better protective effect than rVP19. rVP19+28 showed a lower mortality pattern than rVP28.

These results suggest that the shrimp immune system is able to recognize WSSV structural proteins and the vaccination of shrimp against WSSV might be possible. This opens the way to design new strategies for the treatment of WSSV and other invertebrate pathogens. Further studies on the long term protection from WSSV after the vaccination of shrimp with rVP19+28 as a protein oral vaccine should be carried out.

\section{Acknowledgments}

This work was supported by the Korea Research Foundation Grant funded by the Korean Government (KRF-2008-313-F00084). Dr, Yeong-Jin Kim was financially supported by Pukyong National University in the 2008 Post-Doc. program. Mi Ran Choi was received financial sup- 
port by the fund from Brain Busan 21 project of Metropolitan City of Busan.

\section{References}

1. Escobedo-Bonilla, C. M., V. Alday-Sanz, M. Wille, P. Sorgeloos, M. B. Pensaert, and H. J. Nauwynck. 2008. A review on the morphology, molecular characterization, morphogenesis and pathogenesis of white spot syndrome virus. J. Fish Dis. 31, 1-18.

2. Kurtz, J. and K. Franz. 2003. Innate defence: evidence for memory in invertebrate immunity. Nature 425, 37-38.

3. Musthaq, S. S., K. Yoganandhan, R. Sudhakaran, S. R. Rajesh Kumar, and A. S. Sahul Hameed. 2006. Neutralization of white spot syndrome virus of shrimp by antiserum raised against recombinant VP28. Aquaculture 253, 98-104.

4. Rojtinnakorn, J., I. Hirono, T. Itami, Y. Takahashi, and T. Aoki. 2002. Gene expression in haemocytes of kuruma prawn, Penaeus japonicus, in response to infection with WSSV by EST approach. Fish Shellfish Immund. 13, 69-83.

5. Roux, M. M., A. Pain, K. R. Klimpel, and A. K. Dhar. 2002. The lipopolysaccharide and $\beta-1,3$-glucan binding protein gene is upregulated in white spot virus-infected shrimp (Penaeus stylirostris). J. Virol. 76, 7140-7149.

6. Van Hulten, M. C. W., J. Witteveldt, M. Snippe, and J. M. Vlak. 2001. White spot syndrome virus envelop protein VP28 is involved in the systemic infection of shrimp. Virology 285, 228-233.

7. Venegas, C. A., L. Nonaka, K. Mushiake, T. Nishizawa, and K. Muroga. 2000. Quasi-immune response of Penaeus japonicus to penaeid rod-shaped DNA virus (PRDV). Dis. Aquat. Org. 42, 83-89.

8. Vlak, J. M., J. R. Bonami, T. W. Flegel, G. H. Kou, D. V. Lightner, C. F. Loh, P. C. Loh, and P. W. Walker. 2005. Nimaviridae, pp. 1162, Virus Taxonomy: Eighth Report of the International Committee on Taxonomy of Viruses, Academic Press, London, UK.

9. Witteveldt, J., C. C. Cifuentes, J. M. Vlak, and M. C. W. Van Hulten. 2004. Protection of Penaeus monodon against white spot syndrome virus by oral vaccination. J. Virol. 78, 2057-2061.

10. Wu, J. L., T. Nishioka, K. Mori, T. Nishizawa, and K. A. Muroga. 2002. A time-course study on the resistance of Penaeus japonicus induced by artificial infection with white spot syndrome virus. Fish Shellfish Immunol. 13, 391-403.

\section{초록 : 사료급이(oral feeding)에 의한 vaccination을 통한 흰반점바이러스(WSSV)에 대한 재조합단 백질 rVP19+28의 백신효능의 확인 \\ 응위엔 호아이·김영진 · 최미란·김성구* \\ (부경대학교 생물공학과)}

본 연구는 WSSV의 주요 구조단백질인 VP19와 VP28을 모두 포함하는 VP19+28 fusion protein을 제조하여, Litopenaeus vannamei에서 WSSV에 대한 백신으로서의 효능을 평가하고자 수행하였다. VP19와 VP28 유전자를 fusion하여 제작한 VP19+28 유전자를 pET-28a(+) vector에 삽입하고 단일단백질로서 제작된 VP19+28 유전자를 E. coli BL21 (DE3)에서 발현시켰다. 백신실험을 위해 새우에게 2주 동안 실험용 사료를 급이하였으며, 그 후 바이 러스액 $\left(1 \times 10^{2}\right.$ 배로 희석한 WSSV)을 이용하여 새우에게 주사 감염에 의해 in vivo 공격실험(challenge test)을 수행 하였다. 실험결과, vaccination을 하지 않은 새우들은 감염 후 11 일째에 $100 \%$ 의 누적폐사율을 보였으며, host control로써 E. coli BL21을 사용하여 vaccination한 새우들은 감염 후 17 일째에 $100 \%$ 의 누적폐사율을 보였다. rVP19, $\mathrm{rVP} 28, \mathrm{rVP} 19+28$ 을 이용하여 vaccination한 새우들의 경우 감염 후 21 일째에 각각 $66.7 \%, 41.7 \%, 41.7 \%$ 의 누적폐 사율을 보였다. 이상의 결과를 통해 rVP28과 rVP19+28이 WSSV에 대해 높은 백신효능을 가짐을 확인하였다. 또 한 감염 후 21일째에 fusion protein rVP19+28과 rVP28의 누적폐사율은 동일하였지만 공격실험기간 동안 폐사율 이 rVP19+28을 투여 한 실험군이 낮게 나타나는 것을 보아 WSSV에 대한 새우의 방어효능은 rVP19+28이 더 높 음을 나타내는 것이다. 